\title{
The cultural repertoire of recontextualized superhero in the Avengers sequels
}

\author{
1,2 Musrifatun Nangimah* \\ ${ }^{1}$ Culture, Languages, and Media (KSM) Department, Malmö University, Sweden \\ ${ }^{2}$ Telecommunication Engineering, Faculty of Telecommunication and Electrical \\ Engineering, Institut Teknologi Telkom Purwokerto, Indonesia \\ *Correspondence \\ Email: musrifatun.nangimah@gmail.com
}

Received:

12 January 2021
Revised:

17 May 2021
Accepted:

20 August 2021
Published:

31 August 2021

\begin{abstract}
This research presents content analysis to the cultural repertoire of Marvel Cinematic Universe's superhero motion pictures. It investigates the content, theme, and core ideas of Avengers sequels: The Avengers (2012), Avengers: Age of Ultron (2015), Avengers: Infinity War (2018), and Avengers: Endgame (2019). It explores how the Avengers sequels portrays recontextualization of superhero characters and whether as well as to what extent it provides US cultural monomyth. The finding shows that each character of the Avengers has flaws and vulnerabilities as common human beings that leave them from traditional superhero monomyth. Nevertheless, it still illustrates US cultural imperialism, pharmakon portrayal, hegemonic masculinity, and sovereignty. These motion pictures still serve US heroism and patriotism interest as well as binary interplay: order-chaos, law-violence and villain-superhero that occurs among superheroes, extra-terrestrial race, robots and Titans despite its recontextualized characters. Moreover, it depicts the traditional masculine ideal valorisation where men are more likely powerful, intelligent, and equipped by sophisticated technology whereas women are seen as supportive superheroes with implied beauty standards. The recommendation for future research is discussed.
\end{abstract}

Keywords: Avengers; recontextualized superhero; cultural repertoire; hegemonic masculinity; Marvel Cinematic Universe

\section{INTRODUCTION}

Superheroes have become the center of global popular culture that was originally developed through comic books in the 1960s. As globalization has expanded transnational power, it encourages worldwide free exchange of information and commodities beyond physical territory. In order to reach larger audiences and maximize its profit, transnational media corporations extend the comic books into movies, TV shows, toys, video games, and transform original characters to the fit media format as well as audiences (Chung \& Ju, 2016). This superhero dynamic shift from the comic books into extended formats creates social relations among audiences or is usually called 
Nangimah, M. (2021). The cultural repertoire of recontextualized superhero in the Avengers sequels. EduLite: Journal of English Education, Literature, and Culture, 6 (2), 353-368.

"geek chic" culture. The superhero fandom even differentiates audiences into "hardcore" and "casual" (Beaty, 2016) based on the level of their knowledge and affective intensity regardless their geographical position.

As one of successful superhero media franchises, Marvel Cinematic Universe (MCU) therefore tries to keep its audiences' attention by providing interlinked and extensive continuity of its superhero narratives. MCU does not only provide movies as the narrative per se but also as a means of promotion for their future projects and lucrative franchise creation (Beaty, 2016). It can be seen from its success in creating 22 movie franchises within 12 years and smashing global box-office records on its opening weekend. Avengers: Infinity War (2018) earns $\$ 630 \mathrm{~m}$ overtaking its predecessor box-office record set by The Fate of the Furious $(\$ 542 \mathrm{~m})$ the previous year (BBC, 30 April 2018). Besides, Avengers: Endgame (2019) earns \$1.2bn toppling "Avatar as the highest-grossing film of all time" (The Guardian, 21 July 2019). It shows that superhero movies as one of literature canon are well-received by global citizens regardless of language and cultural differences. Everybody can be "hardcore" or "casual" audience and see movies as US propaganda, purely entertainment, or merely profitable products to whom superhero filmmakers serve the demand.

Some movies may provide cultural landscape as a tourism form (Jewell \& McKinnon, 2008; Peters, Schuckert, Chon \& Schatzmann, 2011), other may use it as a medium to deliver US dominant ideology, especially in superhero movie which focuses on justice-oriented message (Kort-Butler, 2012). How a movie studio, in this case $\mathrm{MCU}$, as an independent profit-oriented global industry works has attracted scholars to explore it academically. The previous research about MCU's superheroes genre have been conducted by using different perspectives. For instance, how Captain America constructs national identity and geopolitical scripts related to America's post-9/11 territorialization (Dittmer, 2005), how the portrayal and critical reception of a Pakistani-American Muslim teenage girl cast as the central superhero, Ms. Marvel seen from feminist perspective (Kent, 2015), how Wiccan and Hulkling from Young Avengers perform gender seen through homonormativity (Dauw, 2018), what are the similarities between European Union (EU) constitutional pluralism law and the Marvel Universe (Davison-Vecchione, 2018), and how MCU's visual vocabulary seen through theological and disability-informed perspective (Martin, 2020). It seems that how the Avengers movie sequels, as MCU's products, portray cultural repertoire has been overlooked. Therefore, this research aims to answer two research questions: how are recontextualized superhero characters seen in the Avengers sequels (1)? Whether and to what extent the Avengers sequels as MCU's recontextualized superhero provide traditional US monomyth (2)? It is seen based on cultural repertoire in terms of cultural imperialism, pharmakon portrayal, hegemonic masculinity, and sovereignty.

\section{Ideological transmission through superhero movie}

It might be argued that movies cannot be seen as a medium for propaganda, cultural imperialism, and gender as well as national identity transformation per se but rather as a filmmaker's tool to get profit or hit franchise through sequels and prequels production. However, the fictional multiverse is 
frequently used as a portrayal or inspired by real life. Film industry, including Hollywood, has succeeded in producing movies based on real life phenomena in different genres. In the superhero genre to name a few, we can see that Marvel creates Captain America to fight the Axis as a response to World War II. As a concern about drug addiction, racism, and social justice in the 1970s, Marvel created Silver Surfer and Spiderman; while its counterpart, DC introduced Green Arrow and Green Lantern. Marvel also introduces Dust, a Muslim superheroine as a member of the New X-men as the response to 9/11 (Davis \& Westerfelhaus, 2013). These superhero movies attract the audiences' huge attention regardless their status whether as hardcore or casual audiences.

Hollywood has achieved global audiences since the 1920s and has become a multinational film industry. It has already been used as an effective medium for American propaganda distribution during and after World Wars, as well as post 9/11 tragedy. As an unofficial propaganda arm, it is a massively influential tool to shape popular opinion (Decherney, 2005). Hollywood contributes to delivering the US supremacy around the globe by producing high-tech and entertaining movies that directly or indirectly support the US ideological empire. It translates and validates popular beliefs and attitudes about the world and the US' role in it through action and superhero movies. It frequently portrays American legitimation, foreign policy, and militaristic themes such as "male heroism, battlefield camaraderie, superpatriotism, violent struggle of good against evil, noble U.S. objectives, and glorification of high-tech warfare" (Boggs, 2010, p.18). In other words, superhero movies can be a means of channeling American ideological, cultural, intellectual, and political hegemony to global audiences. It might not be as firm as Gramsci's in Forgacs (ed, 2000) ideas of hegemony where there is cultural, moral, and ideological leadership and domination, with force, coercion, and imposition of the ruling group over allies and subaltern groups. However, superhero movies discursively frame US government control and individual liberty. It illustrates and incorporates American relation to the international relation. As American pop cultural product in a global context, oddly enough superhero movies fit the local form of nationalism. This genre emerges and justifies exactly the kind of superheroic interventions - manifesting power, morality, and authority to protect the weak (Dittmer, 2013).

Superhero bodies with its superpower naturalizes the idea of national territory. They can intervene in other countries and justify the means to make American values more universal preceding other sovereignty. They have autoimmunity to do what they have to do beyond the states' law, order, legitimacy, and authority. They cannot be controlled by law or rule. Their power allows them to suspend the laws that bind citizens under ordinary conditions (de la Durantaye, 2009). In this notion, the terrain of justice is portrayed ambiguously. Superheroes might constitute peace by doing contradictory action whether in the form of violence or enforcing the law. They still are considered as 'good guys' though they might do self-destructive deeds, breach the law, and destroy state facilities when they fight for justice against supervillains, murderers, terrorists, or the bad guys. Therefore, it is undecidable when the superhero performs action in the name of violence - law, chaos - order, or good - evil. Derrida in Foran (2016) calls this undecidable concept as pharmakon, a 
Nangimah, M. (2021). The cultural repertoire of recontextualized superhero in the Avengers sequels. EduLite: Journal of English Education, Literature, and Culture, 6 (2), 353-368.

double-edged sword of 'poison' and 'remedy'. This unclear binary leaves ambiguous justification for the moviegoers to interpret it.

Moreover, superhero movies mostly are illustrated from male perspective which glorify tactics and technology. Female characters are portrayed as supporting characters either as love interest or mother. They are framed based on their affective personality and appearance. Besides, superheroes emphasize masculine depiction where men are portrayed as independent breadwinners with technological expertise, good physical body, and natural musculature bone (Cumming, 2018). Notwithstanding the masculinity stereotype, Dantzler (2015) believes that MCU as the recontextualized superhero maker will present more heroines in the near future due to its reputation and fast expansion. It is expected that MCU or any other filmmakers produce movies which represent global-concern issues for instance gender equality and issues related to sustainable development goals. Indeed, we cannot use movies as teaching media per se but it reaches wider audiences and becomes effective ways to construct popular opinion and change people's behaviour.

\section{Audiences' cultural repertoire of superhero movie}

Superhero movies bring paradoxical views among the audiences. Some consider superhero movies are constructed only for children and young people. It has a hero worship hazard where the monomyth is fundamentally antidemocratic and it spreads across popular culture controlling consciousness and dictating behaviours. Others believe it as a means to articulate emotions, experiences, social relations, role models, autonomy promotion, and pain relief of sorrow (Hatfield et al., 2013). How a movie is seen depends on the moviegoers. They recreate the literary work by bringing their value, cultural views, attitudes and interpretation. Sell (2014) views a literary work as a form of the work producer's dialogue invitation to the audiences. It brings voices and calls for audiences' response. Bakhtin in Holquist (2005) regards it as polyphonic heteroglossia, in which the various meanings of the literary work depend on the socio-cultural situation. It brings multiple points of views not only from the filmmakers but also from audiences. In this context, the existence of a movie depends on its audiences. It has a different meaning to different audiences at different times with different cultural repertoire.

Swindler (1986) describes cultural repertoire as a set of knowledge, habit, skills, and behaviour where a group of people construct action strategies. In this context, every person approaches life differently based on their active transactional organization. They may develop their action strategies - what to do and how to do a certain action - based on limited self-authority, common sense, norms and values or depend on the ideology which is more embedded as self-conscious belief and ritual practices. Since an ideology directly shapes individual actions, the social transformation should be seen as organizational members' active interpretation and negotiation process. In other words, every individual can choose what behaviour or action they want to conduct to selectively engage the collective presented cultural elements that are perceived "to be aligned as individual repertoires" (Holley, 2011, p. 91).

Regarding that each literary work has intertextuality, MCU's superhero also relates to the mythology in which superheroes experience its monomyth. 
Stan Lee in Mills (2014) explains that an old superhero needs to be perfect and self-sufficient. However, he creates recontextualized Marvel's superhero characters with flaws, vulnerability, and imperfection as normal human beings to make a unique personality that allows transformation. The ability to accept one's weakness and imperfection determines whether a character is a hero or villain. Hero uses its imperfection for good things yet the villain is overwhelmed by it. Lee also makes the character to be human that is needed where the superhero and the supporting characters experience giving and receiving of love. They give their power and get new life meaning. In terms of the hero-villain paradox, Fingeroth (2004) argues that villains embody the dark side of superheroes. They have more well-defined values than the heroes which proactively want to change the world whether because of revenge motives or thirst for power. The idea of vanquishing villains before they destroy society is kind of C. G. Jung notion 'collective unconscious' - the society needs and dreams of heroes. This binary interplay thus will continue to exist so the superhero business will. In spite of audiences' different responses, the geek or other culture will develop along with the movie and media expansion.

\section{METHOD}

In order to answer the research questions and collect the data, I used content analysis to investigate interactive content on the Avengers sequels. The sample of this research was chosen based on purposive sampling strategy as the research goal was not generalizing phenomenon or finding distribution within population. It allowed me to get samples that better match the research aims and gain rigorous results. It is helpful to select the sample based on "analytical, logical, or theoretical grounds" (Berndt, 2020, p.226).

\section{Type of research}

This research utilized content analysis. It offers detailed information about a text where the notion of "a text" here does not only refers to written text but also dialogue, visual, music, production techniques, and film (Neuendorf, 2017). This research method was used since it allowed the researcher focus on the analytical framework development. It helped the researcher to analyze the content, the theme, and the core ideas in the movies as primary contents. Despite its critic on intercoder reliability and validity, content analysis helped the researcher to investigate the intermittent, complex, and contextual meaning, as well as the limited appearance and less important of meaningful content in the text (Drisko \& Maschi, 2016). Considering that visual data gives much room for interpretation and there is no fixed rightness for qualitative content analysis, I acknowledge that this qualitative data might have multiple meanings and interpretations as it is stated by Schreier (2012). In this research, I analysed The Avengers sequels by using content analysis and applying cultural critics to scrutinize the research object. Therefore, it will focus on the cultural epithet rather than give dogmatic ideas. 
Nangimah, M. (2021). The cultural repertoire of recontextualized superhero in the Avengers sequels. EduLite: Journal of English Education, Literature, and Culture, 6 (2), 353-368.

\section{Research object}

This research analyzed four movie sequels of Marvel Studios' the Avengers, namely The Avengers (2012), Avengers: Age of Ultron (2015), Avengers: Infinity War (2018), and Avengers: Endgame (2019). This research focused on the Avengers movie sequels, thus it only sought six superheroes illustrated in the movies rather than the various dynamic Avengers members portrayed in the comic books. These sequels illustrate six-gifted superheroes (Black Widow - Natasha Romanoff, Iron Man - Tony Stark, Hulk - Bruce Banner, Thor, Captain America - Steve Rogers, and Hawkeye - Clint Barton) which fight against different supervillains. The Avengers (2012) focuses on preventing the earth from global destruction. They fight against Loki and his extraterrestrial forces, Chitauri who intend to misuse the translucent blue cube and energy source called Teserract to rule the earth. Avengers: Age of Ultron (2015) illustrates the battle between the Avengers and Ultron, Stark's megabrain initially global defense artificial intelligence which turns into enemies. Instead of fighting against alien forces, the Avengers and the twins Maximoff Quicksilver and Scarlet Witch - save the earth from global extinction by evacuating citizens on the lifted skyward capital city.

On the contrary of the previous two films in which the Avengers face different enemies - aliens, robots, and an Asgardian god; Avengers: Infinity War (2018) and Avengers: Endgame (2019) portray the Avengers' battle against the similar enemy, Thanos, the infinity stones hunter. In the Avengers: Infinity War (2018), the Avengers along with sorcerers, Spiderman, the Guardian of the Galaxy team, and Wakanda forces try to thwart Thanos' plan to collect six infinity stones - the mind, power, reality, soul, space, and time. The Avengers and allies fail to do so. Thanos succeeds collecting the germs, makes it into a gauntlet and eliminates half of life across the universe by simply snapping fingers. In the last movie, Avengers: Endgame (2019), the Avengers and the remaining allies try to recollect the six infinity stones to restore half of the universe's population that had been killed by Thanos. They successfully carry out their mission and kill Thanos, but they lose their key personnel, Tony Stark - the Iron Man.

\section{Data analysis}

The data collection and analysis were conducted by following Erlingsson and Brysiewicz's (2017) content analysis guidance. The first step was to watch and rewatch The Avengers sequel to get a general understanding of what the movies were portraying. After getting the main ideas, the researcher divided the movies' content into smaller meaning units by ensuring the core meaning was still retained. The next step was formulating the codes of the condensed meaning units. It was followed by grouping codes together into categories. These categories then manifested into themes such as cultural imperialism, pharmakon portrayal, hegemonic masculinity, and sovereignty. These thematic data then were interpreted to answer the research problems and inferred into conclusion. 


\section{RESULTS AND DISCUSSION}

\section{The portrayal of recontextualized superhero in the Avengers sequels}

The Avengers become the earth's mighty heroes due to Fury's initiation. As the director of espionage called SHIELD (Strategic Hazard Intervention Espionage Logistics Directorate), he teams six-gifted superheroes up to defend the earth against any threats. Notwithstanding their various backgrounds, each superhero has vulnerable qualities as a common human being. They live in real life and have flaws as Lee explains in Mills (2014). Marvel Cinematic Universe's superheroes, particularly the Avengers, do not serve traditional superhero qualities with its monomyth as perfect supranatural characters. It can be seen from the Avengers sequels. Tony needs Pepper's to run Stark Industry and manage his life (The Avengers, 2012). Hulk needs Black Widow to calm him down and turn into Bruce Banner (The Avengers, 2012; Avengers: Age of Ultron, 2015). Bruce feels insecure and considers that his effect of gamma exposure is a nightmare. So, Tony encourages him to accept it as an inseparable "terrible privilege" to him as Tony does to his electromagnetic heart. Bruce's insecurity and denial can also be seen when he calls his alter ego, Hulk, as "the other guy" and tries to kill himself to escape from Hulk, but he fails to do so (The Avengers, 2012). He cannot transform into Hulk because of his failure feeling after being defeated by Thanos (Avengers: Infinity War, 2018). Only in the last movie, Bruce presents himself as a big guy in daily life. He admits that he used to consider his alter ego, Hulk, as a disease and then after a long experiment he realizes it as a cure and accepts it.

The insecurity feeling is also experienced by other Avengers. Thor, the God of Thunder is illustrated as a soft-hearted person with sentimental and vulnerable sides who puts family first over other matters. Thus, Loki uses his vulnerable character against him (The Avengers, 2012). On the other hand, Captain America experiences a traumatic event - being frozen for ages - and keeps thinking about his lover, Sharon Carter and his home (Avengers: Endgame, 2019). Black Widow wants to do dangerous action for Hawkeye due to her life debt. She also helps Hulk to be Bruce Banner though it endangers herself (The Avengers, 2012; Avengers: Infinity War, 2018; and Avengers: Endgame, 2019). Hawkeye keeps visiting his family members in the unequipped-by-well-developed safety system place which might endanger himself and his families (Avengers: Age of Ultron, 2015 and Avengers: Endgame, 2019). In addition, Avengers: Age of Ultron (2015) shows that Tony Stark aka Iron Man with all his intelligence and sophisticated technology is able to make a mistake. Tony originally designs Ultron as an earth guarding force, yet it turns into an enemy which tries to replace humanity with Ultron sentries.

The fragility and disappointment of each member can be seen in the Avengers: Endgame (2019). The rest of the Avengers (Black Widow, Iron Man, Hulk, Thor, Captain America, and Hawkeye) are in despair after knowing that killing Thanos still cannot bring back their loved ones. Everyone is angry, mournful, and devastated due to the loss. Natasha, who considers the Avengers as the only family she had, was devastated. Tony Stark feels remorse due to their loss. He fights against Thanos in Titan without the Avengers full team while Captain America and other Avengers face Thanos in Wakanda. Tony gets angry and criticizes Captain America for being passive to the evil deed. He says that 
Nangimah, M. (2021). The cultural repertoire of recontextualized superhero in the Avengers sequels. EduLite: Journal of English Education, Literature, and Culture, 6 (2), 353-368.

they are the avengers (doing revenge as a reactive deed) not prevengers (proactively do something without waiting for the cause to prevent something bad happening). His statement justifies Fingeroth's (2004) superhero notion as the reactive side. He also becomes more reserved and lives his life in the lakeside cabin with his family. He focuses on raising his daughter, Morgan and moves away from his superhero routines.

In line with Tony who distances himself from others, Thor as one of the strongest Avenger ends up being an overweight alcoholic guy who has difficulty regaining his confidence. He loses everything, refuses to save the galaxy or leads his people, and chooses to live in a rural area near the lake. Besides, Steve Rogers joins counseling to deal with his difficult emotions. Clint Barton on the other hand, turns into an assassin to get vengeance for losing his family. The Avengers members cope with their loss similarly as common human beings. They need help and time to handle their sorrow and disappointment. They regain hope and motivation to restore things into its places by using a time machine after meeting the unexpected Antman. It shows that the Avengers characters have similar vulnerable qualities as human beings and leaves the old monomyth formula as Lee explains in Mills (2014).

Even though none of Marvel's superheroes in these sequels are handicap or disable, it illustrates that superheroes face their biggest fear or mental health issues. Captain America has to deal with depression. He was frozen for 70 s years and separated from his family, friends, and lover which may cause fear of building new relationships with other people. Black Widow is created to be a great spy by undergoing a traumatic process which forces her to forget her generative dream. Hawkeye has to deal with survival capability and fear of losing his family since he has a dark childhood experience. As the owner of the biggest primary defense company, Tony has to bear huge responsibility to do a peacekeeping mission. He pays his consequences in Avengers: Age of Ultron (2015). Meanwhile, Thor has his own problem of becoming a worthy leader for Asgardians. Bruce struggles accepting Hulk and gets embarrassed whenever somebody talks about the destruction he has made.

Most of the Avengers members own power because of radioactive or beneficial intervention. It distinguishes them from the traditional superheroes which have natural super power as their entities. Thor is the only Avengers member as superhuman or in this context is a god who possesses innate super power. Captain America, Hulk, Iron Man, Black Widow, and Hawkeye get their power due to well-planned serum injection, incidental radioactive exposure and technological augmentation. That is why Avengers members do not have significant differences from moviegoers. Their vulnerabilities put their life in the life of common people. As a result, moviegoers might develop feelings that their superheroes are real characters. They experience ups and downs and live their lives as the way moviegoers do. Moreover, MCU superheroes reside in town, not leaving in the end of the movie as the old superhero pattern. It creates a sense for moviegoers to think or feel that they can bump into their superheroes at school or supermarket.

\section{The traditional US monomyth in the Avengers sequels US cultural imperialism in the Avengers sequels}


The Avengers sequels provide US heroism and patriotism interest by illustrating that each character wants to sacrifice themselves to defend America. Natasha Romanov has to end her interrogation with the Russian officer as soon as Coulson (SHIELD agent) calls. On behalf of SHIELD, she summons Bruce in Calcutta to get the teserract back. As the soldier of America, Captain America is always ready for whatever call his country needs. Though Tony does not want to follow Fury's order to create Avengers, he has a call to get back his tower one of important buildings in New York. Meanwhile, Thor and Clint Barton join the group since they have unfinished business with Loki (The Avengers, 2012). In the Avengers: Age of Ultron (2015), all the Avengers group assembled to fight against Strucker in Sokovia to get the scepter and save the earth from global extinction. They have to fight against Ultron, Tony's supposedly protective robot that turns into an enemy, and evacuate citizens on the lifted skyward capital city. It shows that US patriotism, legitimation, and authority become a thing to be enforced by the Avengers.

In these movies, American value is emphasized where SHIELD exist as counter-terrorism agency around the globe. It shows American legitimation and authority to decide whether one is considered as terrorist or not and whether the group of superheroes need to set the justice or not. Captain America as the symbol of US supremacy also manages to be the leader of the group and linguist police among the members. He makes sure that all the Avengers members act according to his order. Even Thor, the semi-god Asgardian, also obeys his order. Meanwhile, Tony creates a sophisticated artificial intelligent army to protect American from other threats. The unlimited authority of Avengers also can be seen when they put all effort to uphold justice out spaces (Avengers: Infinity War, 2018) and restore half universe 's population that has disappeared due to Thanos' snapping finger. It seems that the best and right way to do this is restoring life though some still remain to disappear (Avengers: Endgame, 2019). This is in line with Boggs' ideas (2010) that US patriotism, legitimation, and high-tech glorification seem frequently seen in the Hollywood movie regardless if the superhero is traditional or recontextualized still emphasizes American and mythology monomyth.

These sequels do not only illustrate the US patriotism but also US values such as individualism, independence, personal control over environment, and competition. Tony confidently does self-proclaim as a genius, billionaire, playboy, and philanthropist when Steve Roger asks him who he is without a suit of armor. He also refuses to follow Fury's order and shows his position as an independent guy when Steve reminds him and Bruce to follow SHIELD's order. Tony also denies Steve's call as 'soldier' which links to the subordination of military hierarchical status (The Avengers, 2012). In addition, each member is portrayed as an independent superhero who has their own expertise. Some are successful single individuals (Natasha, Thor, Bruce, and Steve), others are breadwinners of their families (Tony and Clint). The sequels also promote a sustainable milieu campaign. Stark industry runs its business for a better environment and nation. It offers pure and efficient energy as well as develops robot armies to guard the earth from enemies both alien and extraterrestrial (The Avengers, 2012), though the robots turn into enemies after Ultron is active 
Nangimah, M. (2021). The cultural repertoire of recontextualized superhero in the Avengers sequels. EduLite: Journal of English Education, Literature, and Culture, 6 (2), 353-368.

(Avengers: Age of Ultron, 2015). It also provides an illustration that the Avengers members fight against extraterrestrials, robots, and Titans to protect the earth and other planets from destruction. Even Thanos chooses to live in the beautiful garden - the green space - after he kills half the universe. Further, the sequel presents both teamwork and competition. It can be seen not only competition between superheroes and villains but also among superheroes members. Clint asks Thor to get in line when he wants to fight against Loki. Tony jokes why Thor has a party without inviting him when he fights against Chitauri's army (The Avengers, 2012). Meanwhile, Quil competes with Thor as the captain of the ship before they are apart going to Nidavellir and Knowhere (Avengers: Infinity War, 2018).

\section{US sovereignty in the Avengers sequels}

Regarding sovereignty, one's authority to govern itself can be seen from the activity, institutional, and symbolic power as it is explained by de la Durantaye (2009). The Avengers sequels reveal that superheroes cannot be controlled by law. Avengers members have authority to attack Stucker in Sokovia - an Eastern-European country (Avengers: Age of Ultron, 2015) and Thanos in Titan - out space (Avengers: Infinity War, 2018 and Avengers: Endgame, 2019) though it is beyond American territory. In addition, they have law immunity upon their acts and free from charge though they destroy public facilities during the battle. Hulk has never been sued or sentenced due to his destructive act while fighting against the bad guys. Even though Thaddeus Ross, the secretary of state demands Avengers' responsibility for their action, they get a day off instead (The Avengers, 2012). Captain America warns Ross to stay away from Avengers' decision to do battle, otherwise they will fight him (Avengers: Infinity War, 2018). It also shows that the Avengers members have physical immunity and limitless strength not only because of the injected super soldier serum (Captain America), gamma radiation (Hulk), god's quality (Thor), sophisticated suited armor (Iron Man), but also survival talent (Hawkeye and Black Widow).

These sequels portray Stark Tower as symbolic interest of Avengers sovereign. Loki uses it to launch teserract and open the wormhole for Chitauri army to come to the earth. He does that to get people's attention and validation that he is the earth's ruler (Avengers, 2012). Furthermore, the mise en scene of the Avengers sequel supports it as the symbolic of sovereign. The low angle shot emphasizes that the Stark tower with the carving letter A (after the battle against Chitauri) in New York looks bigger, stronger, and nobler. It becomes Avengers' identity and remains continuously in spite of its damage during the battle. It exists as the Avengers basecamp, recruitment station, and empowerment place for new members. Besides, it shows that the Stark tower supremacy is incomparable. Even, Mjolnir - Thor's hammer - cannot match Stark Tower. It can be seen when Vision (Avengers: Age of Ultron, 2015) and Captain America (Avengers: Endgame, 2019) can lift and use Mjolnir. They do not necessarily become the leader of Asgard even though at the beginning Thor challenges the team and says that anyone who succeeds lifting Mjolnir deserves to be the leader of Asgard. In conclusion, the Avengers sequel present US cultural imperialism and sovereignty. It provides well-manifested US values that are easily received 
by global audiences. So, it does not have to be American to understand it. Global moviegoers might unconsciously agree with this value illustration and receive it as universal values as de la Durantaye (2009) and Dittmer (2013) have already explained. Therefore, Avengers' sequel promotes US values beyond US geopolitical sovereignty which is received by the audiences accordingly without coercion and force.

\section{Pharmakon portrayal in the Avengers sequels}

Considering that superheroes have authority to do what they had to do on behalf of upholding justice, it is undecidable - as Derrida in Foran (2016) calls pharmakon - whether their act is purely good, bad, or in between. Each villain in the Avengers sequels has quite a similar reason to do bad things: being lonely. Loki as Odin's step son feels under Thor's shadow and wants to get validation as a ruler (Avengers, 2012). Thanos cannot enjoy another's presence and wants to get peacefulness by hunting the six infinity stones. He does genocide that he calls "mercy" to balance and save a planet that in his mind is running out of resources. He wipes out half of the universe population - whom he considers as unworthy (Avengers: Infinity War, 2018 and Avengers: Endgame, 2019). Ultron has a slightly different motive. Though Ultron interprets Tony's utterance "into peaceful time" as its mission to fight against humans, it cannot be considered that Ultron is lonely. He is an artificial intelligence that cannot get emotional like human beings (Avengers: Age of Ultron, 2015).

Aside from that, Avengers' sequels emphasize the binary interplay of orderchaos, law-violence and villain-superhero. Fury activates the Avengers to reclaim teserract that has been taken by Loki. It seems that Avengers have responsibility to put things in order though their reaction to Loki's army causes human fear and lot of public facilities destruction. It is undecidable whether Loki's intention to possess teserract makes him the only bad guy in the movie since teserract belongs to universe. Neither Fury nor Loki possess teserract, but both of them have bad intentions. Fury wants to use it to create weapons against the other; while Loki needs it to rule the earth (Avengers, 2012). Furthermore, the furious Hulk destroys everything he sees which sometimes endangers common human beings despite his role as a superhero. On the one hand, Wanda and Pietro Maximoff volunteer themselves to be experimented by hydra and help Ultron due to their vendetta to Tony. Their parents died because of Tony's weapon. Regarding this human experiment, Captain America mentions it as German's way of creating monsters and starting a war despite Agent Hill's assurance that there is no war. Ironically, Captain America is also a human experiment product. On the other hand, Tony's intention to create mega-brain artificial intelligence as the global defense also put the Avengers in an ambiguous situation. Ultron turns to be Avengers' enemy where war is inevitable. Though Ultron partly has free will and Tony is not to blame for the Ultron's alteration (Avengers: Age of Ultron, 2015), it needs clear perspective to see whether these superheroes only do the good things.

Another example of pharmakon illustration in Avengers' sequels is how the Avengers act in the last two movies. Doctor Strange and Scarlet Witch are in a difficult situation where their actions (giving up the time and mind stones) lead to Thanos' victory as the galactic conqueror. The catastrophe around the globe then causes a grieving period (Avengers: Infinity War, 2018). Consequently, the 
Nangimah, M. (2021). The cultural repertoire of recontextualized superhero in the Avengers sequels. EduLite: Journal of English Education, Literature, and Culture, 6 (2), 353-368.

Avengers in Avengers: Endgame (2019) recollect the infinity stones to restore things to five-year prior Thanos snapping fingers. They believe that it is their responsibility to make the world a better place and put things back orderly as a reaction to their failure in Avengers: Infinity War (2018). However, Loki, Natasha, Vision and those who die before the decimation cannot be brought back. Logically, the effect of killing large numbers of the universe population and creating calamity also apply to Iron Man when he snaps his fingers at the end of the movie. Therefore, Thanos cannot be considered as the only bad guy.

These undecidable actions need to be pondered. It depends on the audiences' cultural repertoires whether seeing pharmakon or Avengers members to breach the law in order to set justice, create a chaotic atmosphere, and put humans into fear to maintain the order, or seeing the bad guy as the villain and the good guy as a superhero. Notwithstanding its pharmakon, it is clear that Avengers' sequels portray that superhero acts based on the villain's proactive action. The villains always initiate the movement despite their intention to change the world for power or revenge which is in line with Fingeroth's (2004) explanation. These recontextualized superheroes leave the notion that superheroes' action is a form of what Tony calls as avengers not prevengers. How audiences see the undecidable things in the movie depends on their cultural repertoire as it is described by Bakhtin in Holquist (2005) and Swindler (1986).

\section{The hegemonic masculinity depiction in the Avengers sequels}

Even though Lee in Mills (2014) explains that Marvel's superheroes are already recontextualized by giving human beings vulnerability qualities, the Avengers sequel still depicts the traditional masculine ideal valorization. Men are more likely illustrated as powerful, intelligent, and equipped by sophisticated technology whereas women are seen as supportive superheroes with implied beauty standards. It can be seen that Thor needs Jane and his mother as his comfort. Tony needs Pepper to do his project, Fury needs Maria Hill to manage SHIELD, and Avengers requires Black Widow to calm Hulk, reassure Barton, as well as mediate the Avengers members' argument. However, these sequels only put female characters and heroines as supporting characters. Natasha becomes the usher for Bruce and Steve in the SHIELD's ship. She is also illustrated as the nurturing individual among other superheroes.

Another illustration of male valorization is the lower acceptance of female's capability. Pepper only gets $12 \%$ credit over Tony's mega project despite her total contribution. Tony refuses to give her higher credits due to male physical labor reasons (The Avengers, 2012). Scarlet Witch becomes the vulnerable weirdo telekinetic who attracts problems and needs motivation to face the enemy. Hawkeye tells her that he has to fight against Ultron and cannot babysit Wanda to motivate her to join the group (Avengers: Age of Ultron, 2015). Nebula is portrayed as Thanos' information transmitter, while Gamora becomes the princess that has to be sacrificed for a Soul stone (Avengers: Infinity War, 2018 and Avengers: Endgame, 2019). Another example of female character that experiences male valorization is Shuri. She is portrayed as a brilliant leader for the Wakandan design group. However, her role only supports her brother, king T'chala (Avengers: Infinity War, 2018). 
Apart from being supportive characters, female superheroes are portrayed in the frame of beauty standard: have a well-built body, red hair, light-skin, and possess desirable qualities. It can be seen from Black Widow, Wanda Maximoff, and Captain Marvel. Gamora, Nebula, and Shuri have colour complexion but they have well-built bodies. That is why moviegoers get the notion of beauty standard where having a curved body is something absentia in superhero movies. Moreover, the sequels still portray intelligent gender inequality. Male superheroes are illustrated as smart guys. Tony and Bruce can explain the sophisticated matters about teserract's power, time machine, and nanotechnology. Meanwhile, Black Widow cannot even understand Iron Man's humour "I bring your party" to refer to Chitauri's army during the battle (The Avengers, 2012). As the genius Avenger in the whole four films, Tony always becomes the guy who engineers the technology-related facilities and battle strategies. He also finds that the time machine works to revive people who have been eliminated by Thanos (Avengers: Endgame, 2019). The only male character that looks silly is Quill in the Avengers: Infinity War (2018) and Avengers: Endgame (2019). These sequels also depict the sophisticated facility - links to the male intelligent - that is owned and ruled by male superheroes. Bruce and Tony are illustrated as the genius members who solve complicated problems by doing complex jobs in Stark's high rank research facility.

The masculinity preferences are also revealed in the sequels. All superhero groups, villains, and planets such as Avengers, Guardian of the galaxy, Wakanda, Asgardian, Chitauri, and Titan are led by male superheroes and villains. Captain Marvel is the only female superhero who is in charge of checking planets' security. On top of that, masculinity desire also is seen in Avengers: Infinity War (2018). Drax refutes Quill's terms "dude" to refer to Thor. He explains Thor as a handsome muscular man. So, they should refer to Thor as "this man" rather than "dude". Raccoon agrees to Drax's opinion and comments on Quill's body as way fatter than Thor. Quill is intimidated by Thor especially when Gamora admires Thor's muscles. He tries to compete with Thor by lowering his voice and imitating Thor's action to be more masculine. Besides, Captain America is illustrated as a stereotype of a perfect man and successful superhuman project. Other superheroes even favor and refer to his buttock as desirable "American ass" (Avengers: Endgame, 2019).

In the matter of sophisticated technology, these sequels demonstrate that male superheroes have more sophisticated weapons than their counterparts. Black Widow wears a suit with an ordinary mini revolver. Captain Marvel uses her power without additional weapons. On the contrary, Thor as the semi-god has Mjolnir - a hammer (The Avengers, 2012 and Avengers: Age of Ultron, 2015) and Stormbreaker - a lightning-spewing axe (Avengers: Infinity War, 2018 and Avengers: Endgame, 2019). Iron Man has a sophisticated suit of armors; Captain America has an impenetrable concave-disk vibranium shield; and Hawkeye has a firearm and bow which is equipped by laser. This is in line with Cumming's (2018) explanation that technology expertise and muscular bone are valorized as masculinity.

\section{CONCLUSION}

The Avengers sequels present superheroes with vulnerabilities and flaws which differ from the traditional superheroes. They live and experience bad things as 
Nangimah, M. (2021). The cultural repertoire of recontextualized superhero in the Avengers sequels. EduLite: Journal of English Education, Literature, and Culture, 6 (2), 353-368.

common human beings. As the recontextualized superhero, the Avengers sequels still bring traditional American monomyth. It still portrays that US values, authority, and legitimation prevail among other states. Superheroes can access and uphold justice beyond their basecamp territories. In addition, superhero sovereignty becomes a complex set where the superhero has autoimmunity within its bodies and existence. It is not only seen from their physical body but also from the institutional and symbolic power. The way they react to the bad guys or villains create undecidable phenomena or pharmakon that show binary interplay. Audiences' cultural repertoires will determine their judgment whether the pharmakon of Avengers sequels is seen as the right thing to do, something that puts them in between situations, or it is only a temporary entertainment. This is purely audiences' responses towards its binary interplay which attach to their needs upon superheroes as the collective unconscious expectation. They have freedom to respond whether seeing the sequels as US propaganda, purely entertainment, filmmaker's profitable products, or hazardous popular culture products which control consciousness and dictate behaviours.

The Avengers sequels try to promote gender equality by portraying a number of female superheroes (Black Widow, Scarlet Witch, and Captain Marvel) yet their roles are still as supportive characters along with affective capabilities compared to the masculinity valorization. It is expected that Marvel Cinematic Universe will provide more heroines in their future movies. This research only explores the depiction of superhero recontextualization and cultural repertoire in terms of cultural imperialism, pharmakon portrayal, hegemonic masculinity, and sovereignty. Further research on whether, how, and to what extent these portrayals affect the non-American audiences' interculturality and identity are required.

\section{ACKNOWLEDGEMENTS}

The author would like to thank Rizqi Mulya Iskandar for participating in the theme coding process.

\section{REFERENCES}

Avengers: Infinity War smashes global opening weekend box office record. (2018, April 30). BBC News. https://www.bbc.com/news/entertainment-arts-43944269

Beaty, B. (2016). Superhero fan service: Audience strategies in the contemporary interlinked Hollywood blockbuster. The Information Society, 32(5), 318-325. https://doi.org/10.1080/01972243.2016.1212616

Berndt, A. E. (2020). Sampling Methods. Journal of Human Lactation, 36(2), 224-226. https://doi.org/10.1177/0890334420906850

Boggs, C. (2010). The imperial system in media culture. In and R. V. H. Benjamin Frymer, Tony Kashani, Anthony J. Nocella II (Ed.), Hollywood's exploited: Public pedagogy, corporate movies, and cultural crisis (pp. 13-28). Palgrave Macmillan.

Chung, M.-Y., \& Ju, H. (2016). Transforming authenticity of cultural products: A case 
study of comic characters. Journal of Creative Communications, 11(3), 197-210. https://doi.org/10.1177/0973258616667174

Cummings, K. (2018). "Life Savers": Technology and white masculinities in twitter-based superhero film promotion. Social Media and Society, 4(2), 1-10. https://doi.org/10.1177/2056305118782677

Dantzler, J. Z. (2015). How the Marvel Cinematic Universe represents our quality world: An integration of reality therapy/choice theory and cinema therapy. Journal of Creativity in Mental Health, 10(4), 471-487. https://doi.org/10.1080/15401383.2014.994796

Davis, J., \& Westerfelhaus, R. (2013). Finding a place for a muslimah heroine in the post-9/11 Marvel Universe: New X-Men's dust. In Feminist Media Studies (Vol. 13, Issue 5, pp. 800-809). Taylor \& https://doi.org/10.1080/14680777.2013.838370

Davison-Vecchione, D. (2018). How is the EU like the Marvel Universe? Legal experientialism and law as a shared universe. Law and Literature, 30(2), 185-220. https://doi.org/10.1080/1535685X.2017.1379743

Dauw, D., E. (2018). Homonormativity in Marvel's Young Avengers: Wiccan and Hulkling's gender performance. Journal of Graphic Novels and Comics, 9(1), 61-74. https://doi.org/10.1080/21504857.2017.1288641

Decherney, P. (2005). Hollywood and the culture elite: How the movies became American. Columbia University Press.

Dittmer, J. (2005). Captain America's empire: Reflections on identity, popular culture, and post-9/11 geopolitics. Annals of the Association of American Geographers, 95(3), 626-643. https://doi.org/10.1111/j.1467-8306.2005.00478.x

Dittmer, J. (2013). Captain america and the nationalist superhero: Metaphors, narratives, and geopolitics. Temple University Press.

Drisko, J. W. and Maschi, T. (2016). Content analysis. Madison Avenue, Oxford University Press.

Erlingsson, C., \& Brysiewicz, P. (2017). A hands-on guide to doing content analysis. African Journal of Emergency Medicine, 7(2017), 93-99. https://doi.org/10.1016/j.afjem.2017.08.001

Fingeroth, D. (2004). Superman on the couch: What superheroes really tell Us about ourselves and our society. Continuum.

Foran, L. (2016). Derrida, the subject and the other: Surviving, translating, and the impossible. Palgrave Macmillan.

Forgacs, D. (Ed.). (2000). The Gramsci reader: Selected writings 1916-1935. New York University Press.

Hatfield, C., Heer, J., and Worcester, K. (Eds.). (2013). The superhero reader. University Press of Mississippi.

Holley, K. A. (2011). A cultural repertoire of practices in doctoral education. International Journal of Doctoral Studies, 6, http://informingscience.com/ijds/Volume6/IJDSv6p079-094Holley312.pdf

Holquist, M., (2005). Dialogism. 2nd ed. Taylor \& Francis e-Library.

Jewell, B., \& McKinnon, S. (2008). Movie tourism - A new form of cultural landscape? Journal of Travel and Tourism Marketing, 24(2-3), 153-162. 
Nangimah, M. (2021). The cultural repertoire of recontextualized superhero in the Avengers sequels. EduLite: Journal of English Education, Literature, and Culture, 6 (2), 353-368. http://dx.doi.org/10.30659/e.6.2.353-368

https://doi.org/10.1080/10548400802092650

Kent, M. (2015). Unveiling Marvels: Ms. Marvel and the reception of the new muslim superheroine. Feminist Media Studies, 15(3), 522-527. https://doi.org/10.1080/14680777.2015.1031964

Kort-Butler, L. A. (2012). Justice League? Depictions of justice in children's superhero cartoons. Criminal Justice Review, 38(1), 50-69. https://doi.org/10.1177/0734016812467201

Martin, H. L. (2020). Martyrs and monsters of the Avengers: Christianity and disability in the Marvel Cinematic Universe. Journal of Disability and Religion, 1-9. https://doi.org/10.1080/23312521.2020.1799906

Mills, A. R. (2014). American theology, superhero comics, and cinema: The Marvel of Stan Lee and the revolution of a genre. Routledge.

Neuendorf, K. A. (2017). The content analysis guidebook (2nd ed.). SAGE Publications, Inc.

Peters, M., Schuckert, M., Chon, K., \& Schatzmann, C. (2011). Empire and romance: Movie-induced tourism and the case of the sissi movies. Tourism Recreation Research, 36(2), 169-180. https://doi.org/10.1080/02508281.2011.11081317

Schreier, M. (2012). Qualitative content analysis in practice. SAGE Publications Ltd.

Sell, R. D., 2014. Literature as dialogue: Invitations offered and negotiated. John Benjamins Publishing Company.

Swidler, A. (1986). Culture in action: Symbols and strategies. American Sociological Review, 51(2), 273-286. https://doi.org/10.2307/2095521

Yedroudj, L. (2019, July 21). Avengers: Endgame tops Avatar to be highest grossing film. The Guardian. Retrieved from https://www.theguardian.com/film/2019/jul/21/avengers-endgame-topsavatar-to-be-highest-grossing-film

Conflict of Interest Statement: The authors declare that the research was conducted in the absence of any commercial or financial relationships that could be construed as a potential conflict of interest.

Copyright (c) 2021 Nangimah. This is an open-access article distributed under the terms of the Creative Commons Attribution License (CC BY). The use, distribution or reproduction in other forums is permitted, provided the original author(s) and the copyright owner(s) are credited and that the original publication in this journal is cited, in accordance with accepted academic practice. No use, distribution or reproduction is permitted which does not comply with these terms. 